\title{
Dose regimen for vancomycin not needing serum peak levels?
}

\author{
W-H Tan, N Brown, A W Kelsall, R J McClure
}

Arch Dis Child Fetal Neonatal Ed 2002;87:F214-F2 16

See end of article for authors' affiliations

.....................

Correspondence to: Dr McClure, Neonatal Intensive Care Unit, The Rosie Hospital, Box 226, Addenbrooke's NHS Trust, Cambridge CB2 2QQ, UK. rob.mcclure@msexc. addenbrookes.anglox.nhs.uk

Accepted 6 March 2002

\begin{abstract}
Aim: To determine the safety, efficacy, and need to measure peak serum vancomycin concentrations in a neonatal population using a standard vancomycin dosage regimen.

Method: A total of 101 infants who were admitted to a regional neonatal intensive care unit and received vancomycin $(15 \mathrm{mg} / \mathrm{kg}$ every 12 or 18 hours depending on postnatal age) were studied retrospectively. Infants who had been started on vancomycin before they were transferred to the unit were excluded. The proportion of infants was measured whose serum vancomycin concentrations were within a conservative therapeutic range of trough 5-10 mg/l, peak 20-40 mg/l, and a less conservative, but still safe, range of trough 5-12 mg/l, peak 15-60 mg/l.

Results: Trough concentrations of $5-10 \mathrm{mg} / \mathrm{l}$ were achieved by $46.5 \%$ of infants, and $5-12 \mathrm{mg} / \mathrm{l}$ by $55.4 \%$. Peak concentrations of $20-40 \mathrm{mg} / \mathrm{l}$ were found in $83.2 \%$ of infants, and $15-60 \mathrm{mg} / \mathrm{l}$ in $99.0 \%$. Highest peak concentration was $47.2 \mathrm{mg} / \mathrm{l}$. Some $89.4 \%$ of infants with trough concentrations of $5-10 \mathrm{mg} / \mathrm{l}$ had a peak concentration of $20-40 \mathrm{mg} / \mathrm{l}$.

Conclusions: The vancomycin dosage regimen used in this study produces acceptable therapeutic serum vancomycin concentrations. Peak serum vancomycin concentrations do not need to be measured in neonates using this dosage regimen.
\end{abstract}

V ancomycin is commonly used as part of the treatment for late onset neonatal sepsis because of the high incidence of infections caused by coagulase negative staphylococci, most of which are methicillin resistant. ${ }^{1}$ However, the optimal dosage regimen remains controversial. The value of measuring trough and peak serum vancomycin concentrations is also unclear. $^{23}$ The putative advantage of routine monitoring is that vancomycin dosages may be individualised according to trough and peak serum vancomycin concentrations to ensure that therapeutic concentration is achieved and side effects such as ototoxicity and nephrotoxicity are avoided. ${ }^{4}$ However, it has been suggested that, because vancomycin dosages can be adjusted on the basis of age, weight, and estimated renal function, serum vancomycin concentrations need not be measured. ${ }^{2}$

The various dosage regimens for vancomycin used in premature neonates have been based on pharmacokinetic studies involving small numbers of relatively mature infants. The extent to which these data can be extrapolated to very premature infants is unclear. Several studies have suggested that vancomycin clearance correlates most strongly with postconceptual age (PCA), ${ }^{5-9}$ whereas others have found that renal function, as indicated by serum creatinine, is the best predictor. ${ }^{10-12}$ Although some authors have found an association between postnatal age and vancomycin clearance, ${ }^{413}$ others have not been able to confirm this. ${ }^{6812}$ In addition, renal function in premature neonates remains relatively immature up to a PCA of 34 weeks. ${ }^{8}$ It is not surprising that recommended dosage regimens vary considerably.

There have been few studies on the appropriateness of vancomycin dosage regimens that have involved extremely premature infants or examined the need to measure serum vancomycin concentrations in this population. We undertook a retrospective study of an historical cohort to both assess the suitability of the vancomycin dosage regimen used in our neonatal unit across a wide range of PCA, and to determine the necessity of measuring serum vancomycin concentrations.

\section{METHODS}

All infants who were admitted to the neonatal intensive care unit, The Rosie Hospital, Cambridge, and received vancomycin from 1 January 1998 to 31 March 2000 were considered for inclusion in the study. Infants admitted from other hospitals who had received vancomycin using different dosage regimens were excluded. Ethical approval for the study was given by the relevant local hospital ethics committee.

The vancomycin dosage regimen used was $15 \mathrm{mg} / \mathrm{kg}$ every 18 hours for infants up to 1 week of age, and $15 \mathrm{mg} / \mathrm{kg}$ every 12 hours for infants more than 1 week old irrespective of PCA. This was a compromise dose derived from various sources including the British National Formulary and the Northern Neonatal Network Neonatal Formulary. ${ }^{14}{ }^{15}$ Each dose was administered as an intravenous infusion over a period of 60 minutes.

The proportion of infants with trough and peak serum vancomycin concentrations within two therapeutic ranges was determined. The first, a conservative range (range A; 5-10 $\mathrm{mg} / \mathrm{l}$ for trough concentrations, and $20-40 \mathrm{mg} / \mathrm{l}$ for peak concentrations), was set by our own microbiology department, and has been recommended previously. The second, less conservative, range (range $\mathrm{B} ; 5-12 \mathrm{mg} / \mathrm{l}$ for trough concentrations, and $15-60 \mathrm{mg} / \mathrm{l}$ for peak concentrations) was obtained from studies that have suggested that peak concentrations above 15 $\mathrm{mg} / \mathrm{l}$ are adequate, ${ }^{16}$ and that trough concentrations up to 12 $\mathrm{mg} / \mathrm{l}$ and peak concentrations up to $60 \mathrm{mg} / \mathrm{l}$ are not associated with any serious toxicity. ${ }^{5}$ Blood samples for assay of serum vancomycin concentrations were taken around the third dose. Trough samples were taken just before vancomycin was given, and peak samples were taken one hour after the end of the infusion. Serum vancomycin concentrations were measured by fluorescent polarisation immunoassay (TDx, Abbot Laboratories, Abbott Park, Illinois, USA), and the results were recorded on the microbiology laboratory computer system (MediTech HCIS, Boston, Massachusetts, USA). Data for this study were obtained from this database retrospectively. The following parameters were also recorded: date of birth, date of 


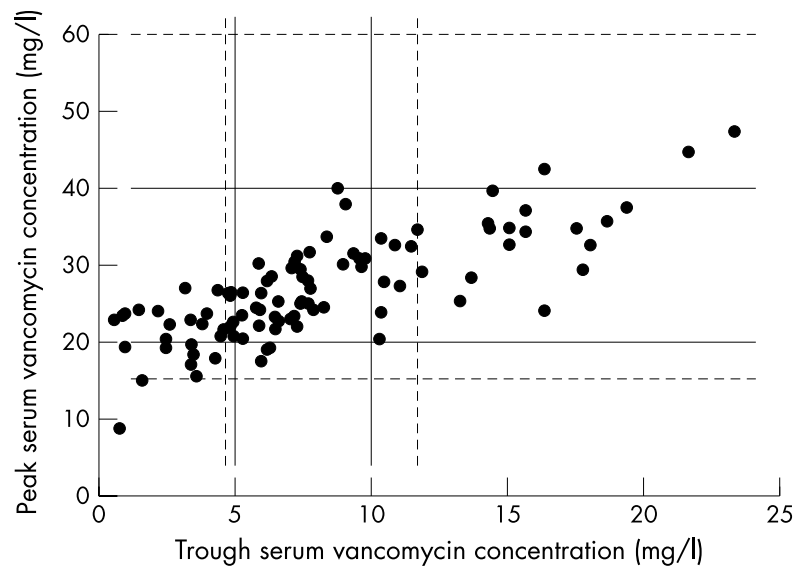

Figure 1 Paired values for trough and peak serum vancomycin concentrations. Solid lines show outer limits of range A, and dashed lines show outer limits of range $B$.

specimen, gestational age, and serum creatinine concentrations in the preceding two days before serum vancomycin concentrations were measured.

To assess the effect of PCA on serum vancomycin concentration, infants were divided into three subgroups according to PCA: less than 28 weeks, 28-34 weeks inclusive, and greater than 34 weeks. To assess the importance of renal function, mean serum creatinine concentrations for infants with high $(>12 \mathrm{mg} / \mathrm{l})$ trough vancomycin concentrations were compared with those with therapeutic or low trough vancomycin concentrations.

The proportion of infants whose trough and peak serum vancomycin concentrations were both within the therapeutic ranges in the different subgroups was compared using the $\chi^{2}$ test. Mean serum creatinine concentrations were compared using Student's $t$ test.

\section{RESULTS}

A total of 101 patients were recruited. The median gestational age was 28 weeks (range 23-41), median postnatal age was 10 days (range 4-99), and median PCA was 30 weeks (range 23-45). Thirty two patients had a PCA of less than 28 weeks, 48 patients were $28-34$ weeks, and 21 patients were more than 34 weeks. Fifty eight patients received vancomycin at 12 hourly intervals, and 43 received vancomycin at 18 hourly intervals.

Figure 1 shows the paired values for trough and peak serum vancomycin concentrations for each infant. The median trough serum concentration was $7.1 \mathrm{mg} / \mathrm{l}$ (range 0.6-23.4), and the median peak serum concentration was $25.5 \mathrm{mg} / \mathrm{l}$ (range 9.0-47.2). The maximum peak concentration was 47.2 $\mathrm{mg} / \mathrm{l}$ in an infant of PCA 31 weeks. This infant also had the highest trough concentration of $23.4 \mathrm{mg} / \mathrm{l}$. About $42 \%$ of the infants had both trough and peak concentrations within therapeutic range A. Of the 47 infants with trough concentrations of 5-10 mg/l, only four had peak concentrations less than $20 \mathrm{mg} / \mathrm{l}$, and only one had a peak concentration greater than $40 \mathrm{mg} / \mathrm{l}$ (range of peak concentration 17.6-40.2 mg/l). Some $83 \%$ of infants had a peak concentration within range A.

Over half $(55 \%)$ of infants had both trough and peak concentrations within the therapeutic range B. No infant had a peak concentration above the upper limit of range $B$, and only one (PCA 45 weeks) had peak concentration less than the lower limit of $15 \mathrm{mg} / \mathrm{l}$ (trough: $0.8 \mathrm{mg} / \mathrm{l}$; peak: $9.0 \mathrm{mg} / \mathrm{l}$ ).

There was no significant difference, across the three PCA subgroups, in the proportion of infants whose peak and trough concentrations were both within the therapeutic concentrations for range A $(p=0.17)$. Similar analysis using
Table 1 Proportion of infants in each postconceptional age (PCA) subgroup with both trough and peak concentrations within the respective therapeutic ranges

\begin{tabular}{llll}
\hline & PCA $<28$ weeks & PCA 28-34 weeks & PCA $>34$ weeks \\
\hline Range A & $9 / 32(28)$ & $23 / 48(48)$ & $10 / 21(48)$ \\
Range B $17 / 32(53)$ & $29 / 48(60)$ & $10 / 21(48)$ \\
\hline
\end{tabular}

The first value is the number of infants with both trough and peak vancomycin concentration in the respective intended range. The second value is the total number of infants in each PCA subgroup. Values in parentheses are percentages.

range $B$ again found no significant difference among infants of different PCA $(\mathrm{p}=0.58)$ (table 1$)$.

Serum creatinine concentrations in the 18 patients whose trough vancomycin concentrations exceeded $12 \mathrm{mg} / \mathrm{l}$ were significantly higher than those whose trough concentrations were below $12 \mathrm{mg} / \mathrm{l}$ (70.4 (3.4) (64.0 to 76.8 ) v 51.7 (2.1) (47.6 to 55.8$) \mu \mathrm{mol} / \mathrm{l} ; \mathrm{p}<0.00005$; means (SEM) (95\% confidence interval of the mean)).

\section{DISCUSSION}

The serum concentrations of vancomycin compare favourably with those measured in studies using different dosage regimens in premature infants. Koren and James ${ }^{18}$ found that $75 \%$ of their 32 premature infants (mean (SD) PCA 34.2 (3.5) weeks) achieved their target trough concentration of less than $10 \mathrm{mg} / \mathrm{l}$, and $67 \%$ achieved peak concentrations of $25-40 \mathrm{mg} / \mathrm{l}$ (compared with $73 \%$ and $83 \%$ respectively in this study). McDougal et $a l^{9}$ in their study of 44 infants with a PCA of 27-44 weeks found that $25 \%$ of the infants achieved the targeted trough concentration of 5-10 mg/l (compared with $47 \%$ in this study), and $64 \%$ achieved a peak concentration of 25-35 mg/l. Neither study analysed the proportion of infants whose trough and peak concentrations were both within the therapeutic ranges.

The greatest concern about the use of vancomycin is the potential for ototoxicity and nephrotoxicity. The incidence of these side effects and the vancomycin concentrations at which they occur remain controversial. ${ }^{3}$ Although there have been a few reports of ototoxicity in the adult population, most of the patients had received other drugs known to be ototoxic, and irreversible deafness occurred only with serum vancomycin concentrations above $80 \mathrm{mg} / \mathrm{l}^{2}{ }^{19-21}$ There have been no reported cases of ototoxicity caused by vancomycin in neonates. Nephrotoxicity is thought to occur in $5 \%$ of adult patients treated with vancomycin, and in most of these cases the nephrotoxicity was reversible. ${ }^{219}{ }^{20}$ In the newborn, vancomycin induced nephrotoxicity is relatively rare. None of the 69 infants (PCA 26-54 weeks) in the study of Bhatt-Mehta et al ${ }^{17}$ developed nephrotoxicity even with trough vancomycin concentrations up to $39.4 \mathrm{mg} / \mathrm{l}$ and peak vancomycin concentrations reaching $49.7 \mathrm{mg} / \mathrm{l}$.

The minimal inhibitory concentration of vancomycin against Staphylococcus epidermidis and Staphylococcus aureus is generally in the range $0.5-2 \mathrm{mg} / \mathrm{l}^{22}$ As vancomycin is $50 \%$ protein bound, it has been suggested that serum vancomycin concentrations should be kept above $2-4 \mathrm{mg} / \mathrm{l}^{2}$ The key determinant of bactericidal activity rests on the length of time during which serum vancomycin concentration remains above the minimal inhibitory concentration. ${ }^{3}$ There is little evidence that the rate of bacterial killing increases at concentrations above the minimal inhibitory concentration, ${ }^{23}$ and peak concentrations do not affect clinical efficacy or toxicity. ${ }^{23}$ Thus the routine measurement of peak serum vancomycin concentration is of dubious clinical value as it gives little, if any, useful information about possible toxicity or bactericidal efficacy. 
With our dosage regimen, no infant had a peak serum vancomycin concentration above the conservative range A if they had a trough concentration within the therapeutic range A or B. All infants had peak serum vancomycin concentrations well below $60 \mathrm{mg} / \mathrm{l}$ (maximum concentration $47.2 \mathrm{mg} / \mathrm{l}$ ). Only one patient had an inappropriately low peak vancomycin concentration at less than $15 \mathrm{mg} / \mathrm{l}$, and that was associated with the lowest trough concentration of $0.8 \mathrm{mg} / \mathrm{l}$. Trough concentrations below $5 \mathrm{mg} / \mathrm{l}$ were never associated with peak concentrations above $40 \mathrm{mg} / \mathrm{l}$, and trough concentrations above $10 \mathrm{mg} / \mathrm{l}$ were never associated with peak concentrations below $20 \mathrm{mg} / \mathrm{l}$. These data suggest that vancomycin dosages in premature or term infants can be safely and routinely adjusted up or down on the basis of trough concentration monitoring alone. The one exception to this may be in infants with established renal failure, as we have shown that potentially toxic trough concentrations are associated with significantly higher creatinine concentrations.

In conclusion, the dosage regimen used in this study results in acceptable therapeutic serum vancomycin concentrations in premature infants. Trough serum vancomycin concentrations should continue to be measured to avoid possible toxicity, and to ensure that adequate dosing is achieved. Routine measurement of peak serum vancomycin concentrations, however, appears to be unnecessary. Currently in the United Kingdom, the incremental cost of each vancomycin assay is about $£ 10$. Abandoning the measurement of peak serum vancomycin concentrations should result in significant financial savings as well as of laboratory and sampling manpower time. It will also reduce unnecessary trauma to infants.

\section{ACKNOWLEDGEMENTS}

We are grateful to Dr Toby Prevost, Centre for Applied Medical Statistics, University of Cambridge, for his expert statistical advice. We thank the staff of both the neonatal unit and microbiology laboratory of Addenbrooke's NHS Hospital Trust for performing the vancomycin assays.

\section{Authors' affiliations}

W-H Tan, A W Kelsall, R J McClure, Neonatal Intensive Care Unit, The Rosie Hospital, Box 226, Addenbrooke's NHS Trust, Cambridge CB2 2QQ, UK

N Brown, Department of Clinical Microbiology and Public Health Laboratory, Box 236, Addenbrooke's NHS Trust

\section{REFERENCES}

1 Isaacs D. Rationing antibiotic use in neonatal units. Arch Dis Child Fetal Neonatal Ed 2000;82:F1-2.

2 Cantú TG, Yamanaka-Yuen NA, Lietman PS. Serum vancomycin concentrations: reappraisal of their clinical value. Clin Infect Dis 1994; 18:533-43.

3 MacGowan AP. Pharmacodynamics, pharmacokinetics, and therapeutic drug monitoring of glycopeptides. Ther Drug Monit 1998;20:473-7.

4 Rodvold KA, Evereft JA, Pryka RD, et al. Pharmacokinetics and administration regimens of vancomycin in neonates, infants and children. Clin Pharmacokinet 1997;33:32-51.

5 Leonard MB, Koren G, Stevenson DK, et al. Vancomycin pharmacokinetics in very low birth weight neonates. Pediatr Infect Dis J 1989:8:282-6.

6 Naqvi SH, Keenan WJ, Reichley RM, et al. Vancomycin pharmacokinetics in small, seriously ill infants. American Journal of Diseases in Children 1986;140:107-10.

7 James A, Koren G, Milliken J, et al. Vancomycin pharmacokinetics and dose recommendations for preterm infants. Antimicrob Agents Chemother 1987;31:52-4.

8 Reed MD, Kliegman RM, Weiner JS, et al. The clinical pharmacology of vancomycin in seriously ill preterm infants. Pediatr Res 1987;22:360-3.

9 McDougal A, Ling EW, Levine M. Vancomycin pharmacokinetics and dosing in premature neonates. Ther Drug Monit 1995;17:319-26.

10 Schaible DH, Rocci ML, Alpert GA, et al. Vancomycin pharmacokinetics in infants: relationships to indices of maturation. Pediatr Infect Dis J 1986:5:304-8.

11 Jarrett RV, Marinkovich GA, Gayle EL, et al. Individualized pharmacokinetic profiles to compute vancomycin dosage and dosing interval in preterm infants. Pediatr Infect Dis J 1993;12:156-7.

12 Grimsley C, Thomson AH. Pharmacokinetics and dose requirements of vancomycin in neonates. Arch Dis Child Fetal Neonatal Ed 1999:81:F221-7.

13 Silva $R$, Reis E, Bispo MA, et al. The kinetic profile of vancomycin in neonates. J Pharm Pharmacol 1998;50:1255-60.

14 Vancomycin. In: British national formulary 42. London: BM Publishing Group, 2001:276-7.

15 Vancomycin. In: Neonatal formulary. 10th ed. London: BM Publishing Group, 1998:228.

16 Miles MV, Li L, Lakkis $H$, et al. Special considerations for monitoring vancomycin concentrations in pediatric patients. Ther Drug Monit 1997;3:265-70.

17 Bhatt-Mehta V, Schumacher RE, Faix RG, et al. Lack of vancomycin-associated nephrotoxicity in newborn infants: a case-control study. Pediatrics 1999;103:e48

18 Koren G, James A. Vancomycin dosing in preterm infants: prospective verification of new recommendations. J Pediatr 1987;1 10:797-8.

19 Saunders NJ. Why monitor peak vancomycin concentrations? Lancet 1994:344: 1748-50.

20 Duffull SB, Begg EJ. Vancomycin toxicity. What is the evidence for dose dependency? Adverse Drug React Toxicol Rev 1994;13:103-14.

21 Fanos V, Dall'Agnola A. Antibiotics in neonatal infections: a review. Drugs 1999;58:405-27.

22 Schaad UB, McCracken GH Jr, Nelson JD. Clinical pharmacology and efficacy of vancomycin in pediatric patients. J Pediatr 1980;96:119-26.

23 Shackley F, Roberts $P$, Heath $P$, et al. Trough-only monitoring of serum vancomycin concentrations in neonates. J Antimicrob Chemother $1998 ; 41: 141-2$ 